\title{
Globalization, Educational Targeting and Stable Inequalities: a Comparative Analysis of Argentina, Brazil and Chile
}

\author{
Xavier Rambla (avier.rambla@uab.es) \\ Seminari d'Anàlisi de la Política Social (selene.uab.es/_cs_gr_saps) \\ Departament de Sociologia, Universitat Autònoma de Barcelona \\ Campus de Bellaterra- Edifici B 08193- Cerdanyola del Vallès (Barcelona: Espanya) \\ Draft. Final verstion published in International Review of Education (UNESCO \\ Institute of Education, Hamburg)
}

Volume 52(1-2), 2006 Education for Social Justice Special Double Issue: Guest-editors: Joseph Zajda, Suzanne Majhanovich and Val Rust

\begin{abstract}
This article analyzes educational targeting in Argentina, Brazil and Chile from a sociological point of view. In essence, it presents the 'logic of induction' as an ideal type. This pedagogic discourse is the vehicle of an educational anti-poverty strategy that expects to induce clearly targeted groups to improve on their own. The analysis explores the influence of the global educational agenda, the empirical connection between this discourse and the mechanism of emulation as well as the territorialization of educational inequality. Emulation plays the main role inasmuch as the logic of induction eventually leads the target groups to compare their adverse situation with more privileged groups, what legitimizes the current structures of categorical inequality (Tilly 1998). Finally, a brief statistical summary reports that the trends of educational inequality have remained stable as far as urban- rural ratios (in Brazil and Chile) and regional disparities (in the three countries) are concerned.
\end{abstract}

Keywords Globalization. Education Policy. Educational Inequality. Anti-poverty policy. Latin America 
This article presents the theoretical rationale and the first empirical findings of a research project on globalization, anti-poverty and education policies carried in Argentina, Brazil and Chile (see note 1). Following the recommendations included in the global educational agenda, since the nineties these three countries have experienced with educational targeting as a means to alleviate poverty. My point is that targeting itself has contributed to stabilize rather than reduce educational inequalities, because this anti-poverty strategy triggers the emulation mechanism. However, it also opens a political contention whose outcome is still open. Although the article will not analyze them, in the last years new articulations of anti-poverty and education policies have just been designed and implemented in order to stretch equity- driven educational intervention in these countries.

The text is divided into four parts. The first two ones define the concepts of globalization, educational inequalities and emulation that have been used in the research. The final two ones report findings of emulation and stable educational inequalities in the three countries (see note 2).

\section{Globalization and the education policy agenda}

Several specialists in education policy have convincingly argued that globalization has impinged on this area of state activity by establishing an agenda that includes the official objectives and instruments of education. A salient novelty is that nowadays states themselves, international organizations, corporations and social movements try to fashion the agenda at the global level of political decision (Carnoy 1999, Dale 1999, 2000, Bonal 2002, Robertson, Bonal and Dale 2003). Since this is another face of the complex, multi-scalar processes that have brought about globalization (Jessop 2001), these authors provide quite a useful theoretical framework to explore how education and anti-poverty policies have been combined.

In their view, globalization impinges on the education policy agenda by means of rescaling processes. Re-scaling takes place between the global, global- regional, state, sub-state regional and the local levels of politics and policy-making. Observers have noticed that states have lost (or decided to lose) very crucial competencies in favor of global markets (e.g. telecommunications, accounting) and international organizations (e.g. trade) (Strange 1996). Similarly, the World Bank conditioned loans, the UNESCO Education for All program and the WTO GATS negotiation have introduced education in international politics (Bonal 2002). Actually, Argentina, Brazil and Chile have complied with the core global recommendations issued by the WB, UNESCO and the Inter-American Development Bank, the Economic Commission for Latin America and other supra-national bodies in the continent. Two kinds of reasons seem to have persuaded their governments, either a notorious will to implement the 'best practices' (mostly, Chile) or a combination of external imposed conditions and internal political projects (Argentina and Brazil). Scale shifts have also entailed de-centralization: thus, for the last two decades Argentinean provincias, Brazilian estados and Chilean municipalities have become the main educational authorities.

Educational targeting is an outcome of policy re-scaling in Southern America. Roughly speaking, this anti-poverty strategy consists of positive pedagogic and/ or economic discrimination of the worst off in order to improve their performance, alleviate their poverty and reduce general inequality. Often, it also aims to 'activate' students and their 
parents in order to improve their academic results, their labor strategies or simply their capability to ask for the social services they need. For instance, the World Bank (2001, 2004) recommends educational targeting as a key tool to guarantee economic opportunities, empowerment spaces and integral security for the poor keeping a balance between selective action and minimal but universal education, health and pension systems. The Inter- American Development Bank has also added targeting to its education policy guide for the governments in the region (Castro 2000). And the Economic Commission for Latin America (CEPAL) has emphatically promoted targeting for the last decade. Recently, CEPAL (2002) has estimated and welcome a middle-term decline of illiteracy and drop-out rates in the region; as a consequence, the Economic Commission expects that the poor are endowed with more years of schooling and therefore get greater economic returns.

In Argentina educational targeting and full de-centralization were implemented almost simultaneously in the early nineties. Most educational competencies were transferred to regional governments (provincias). The Social Educational Plan (Plan Social Educativo) was the only initiative that the central government directly managed. It offered pedagogic support and management consultancy to the worst performing schools and delivered grants to the poorest households. After the 2001 crisis the Kirchner government has replaced that plan with the Integral Plan for Educational Equality (Plan Integral para la Igualdad Educativa), that aims to implement pro-poor action beyond strict targeting. In Brazil municipalities and regional governments (estados) are in charge of primary and secondary education, although some Federal initiatives have been undertaken. At first, the government tried to raise enrolment via school-based management but in the late nineties it also decided to give a grant to students coming from poor households (School Grant, Bolsa Escola). Afterwards, ome local authorities have deployed similar schemes, and the new Lula government has issued a blueprint of a benefit that integrates educational, food and housing aid. In Chile the dictatorship transferred school management to local authorities in the eighties. Educational pedagogic targeting became one of the main instruments that the first democratic government promoted in primary schools against poverty and inequality (900 Schools Program, Programa 900 Escuelas). Since 2000 President Lagos has decided to emphasize targeting in secondary schools, combining both economic aid for families and pedagogic and management support for schools (High-school for All Program, Programa Liceo para Todos).

Like CEPAL (2002), most policy-makers have made their decisions on the grounds that the Argentinean, Brazilian or Chilean education system suffered from important shortcomings, even though they simply expected to push on the declining literacy, enrolment and drop-out rates recorded after democratic transitions. My analysis takes account of these expectations and the associated assumptions in order to look for a sort of evidence that is different to the indispensable evaluation studies. Whereas these ones produce evidence for decision-making by spelling out the connections between the objectives, implementation and impacts of programs, I will focus on the content analysis of the official discourse about educational targeting for several theoretical reasons. On the one hand, educational policies and the re-scaled educational agenda are likely to deploy rhetorical strategies of legitimization (Dale 1989; Ball 1994; Popkewitz 1994). On the other hand, in the same way as educational messages are normally recontextualized into the academic and the official fields (Bernstein 1990, 1996), such recontextualization is probably amplified with re-scaling. Actually, targeting transmits 
and translates educational messages from one context to another: namely, from international organizations to national governments, from national official programs to academic discourse, from national programs to schools and from schools to families and children. Besides implementing positive discrimination, targeting also delimits who are the needy and what are they supposed to learn in order to see their condition improved.

A research object must be defined to answer this question (Bourdieu and Wacquant 1992). In my view, the logic of induction is an appropriate label to conceptualize the focus of my analysis, which is an element of the official and academic pedagogic discourses too (Bernstein 1990, 1996). By 'logic' I mean that this discourse entails a definition of the poor and their ideal behavior. Actually, this strategy asks program managers and school teachers to distinguish their beneficiaries in a clear and objective way. Different records produce lots of necessary data to define target groups: either a questionnaire, an academic examination, a certification of income or the systematic observation of social workers are useful to estimate who should be targeted, if this population is effectively covered, if some beneficiaries don't deserve the benefit and so on. With 'induction' I mean the will to activate the target group so that the poor or the low performing students learn to succeed autonomously. In other words, they are 'induced' to be autonomous social and economic actors who overcome their adverse material situation on their own. So, this 'logic' expects that 'induction' triggers a particular causal process of poverty reduction.

The logic of induction is an ideal type, that is, the concept highlights the more significant and common traits of heterogeneous realities. Sociologists are very fond of ideal types: for instance, Max Weber and Karl Manheim designed ideal types to study work ethics and conservatism. Recently, other ones have been helpful to spell out the clues of the 'new capitalism' (Fairclough 2003) and the 'new imperialism' (Tikly 2004). Mine is a more specific issue but draws on an analogous procedure. Once we identify the features of these discourses in a context, we can inquire which political orientation eventually determines the logic of induction: either poverty alleviation by means of targeting, or social control by establishing hierarchical social rules. Doubtless, these orientations can also face possible conflicts with social agents who support alternative interests and worldviews, since they do not emerge from a historical void.

\section{Emulation and educational inequalities}

In my opinion, the logic of induction hardly contributes to alleviate educational inequality. This argument requires to complement the former analytical concept with three definitions that take account of inequality, emulation and territorialization. A sensible hypothesis would state that the logic of induction contributes to keep a stable educational gap mostly between social classes and ethic groups, albeit at higher school cycles. Such divide is visible in territorial terms due to the location of these groups. Inter alia, one main causal mechanism of this stability arises from the logic of induction. As a discourse, it sets social representations that feature the local poor and legitimizes operational decisions that trigger emulation by asking them to assimilate remote and alien patterns of behavior. At last, it is other people such as national and global decision- makers, program managers and scholars who blame them for their actual social practices and associate the alternative pattern with a higher prestige. My analysis explores how targeted programs outline educational inequality by establishing who have a weak educational potential and the way to overcome this deficit. 
Generally speaking, the former effect is another symptom of globalization. This is a complex, multi-scalar process (Jessop 2001) whereby both the institutional space of educational decision- making and the role of education in the prevailing territorial matrix undergo deep transformations. Multi-scalar political processes institute new rules of emulation by means of certain anti-poverty strategies; people apply these rules at the same time as they experience other causal mechanisms that eventually shape categorical inequality and territorial educational inequality too. Complex causality is at stake inasmuch as several and heterogeneous factors impinge on social inequality.

Social inequality emerges when the distribution of a resource is biased against some individuals; it is much more perverse if they cannot develop their basic capabilities due to this lack (Sen 1999). As to education, statistical data report inequality with regards to literacy, enrolment, drop-out rates, graduation and performance. Such information makes reference to credentials and cognitive learning, but there is no official information about basic capabilities such as imagination, affiliation or care that are involved in education too (Nussbaum 2000). In spite of their partial scope, these data can be very useful if they are read at different thresholds, since inequality is clearly worse when recorded at the lower educational levels. The UNDP (2004) Education Index portrays these thresholds by measuring literacy and enrolment (at primary, secondary and university levels). Other sources (CEPAL 2002, Government of Argentina- Ministry of Education 2002, Government of Chile- Ministry of Education 2000, 2004, Government of Brazil- Ministry of Education 2004) provide further details about educational processes and outcomes. Thus, the trend of educational inequalities in Argentina, Brazil and Chile can be easily assessed drawing on this partial ordinal measures of enrolment and achievement at primary and secondary levels.

Charles Tilly's (1998: 10) concept of emulation is the main hermeneutic tool that grasps the links between the logic of induction and inequalities. In Tilly's view, inequalities are pervasive and episodic due to many circumstances, but they become durable when a biased distribution roots on structural categories such as class, gender or ethnicity. Then any local distributional bias is reinforced by supra-local economic and political power through the individuals' previous understanding of the situation. Basically, two mechanisms create these categorical inequalities, namely exploitation (a category commands resources and gets the most out of alien labor) and opportunity hoarding (a category monopolizes access to a valuable resource). And two further mechanisms generalize their influence: namely, emulation (the transplanting of social norms) and adaptation (the legitimization of inequality through daily routines). The logic of induction impinges on social inequality by reinforcing emulation, which works in the frame of this wider multi-causal set.

By defining the category of the needy and requiring them to change their social practices, the logic of induction easily transplants the social rules of endeavor and individual success from the professional privileged to the popular disadvantaged social contexts. Formally, technical recommendations, reports and previous evaluations of unconditional benefits have concluded that targeting and activation would tap the potential human creativity of the poor (CEPAL 2002; World Bank 2004). However, in a local school or in a local urban area targeted schools and students constitute a very visible, powerless and poor social category within the implicit but real and broader categorical inequality. Under these circumstances pervasive hierarchical comparison 
threatens to overrun the liberation of that potential. A content analysis of official discourse indicates whether the promoters of this strategy look for convincing proofs of its alleged stimulating effects, or rather take the game of hierarchical comparisons for granted and eventually legitimize categorical inequality by institutionalizing this social norm.

With regards to Argentina, Brazil and Chile, Tilly's (1998) analysis suggests that educational inequalities have declined because the democratic governments promulgated the universal right to education, and thus neutralized educational opportunity hoarding. Before, many women, urban popular classes, ethnic minorities and peasants were excluded from education simply because there were not schools for them, but literacy and enrolment have certainly increased in spite of economic hardship after democratic transitions. However, important shortcomings persist and income poverty keeps damaging the very conditions of education (Tedesco and López 2002). Thus, the general trend has been initial equalization and later stagnation. A plausible explanation of this pattern could hypothesize that the final institutional arrangements and official programs eventually favored emulation. The available evidence can indicate whether the logic of induction enacts emulation through hierarchical comparisons instead of effectively introducing the poor in labor markets and collective decisionmaking processes.

Furthermore, the very logic of induction and the resulting emulation finally impinge on territorial inequality too. Robertson, Bonal and Dale (2003) have borrowed some geographical concepts from Brenner (1999) and Harvey (2000) in order to analyze education policy. Generally, geographers argue that human agency transforms space into particular territories by different means such as boundaries, communications, consumption, social movements and identity. This multi- causal, continuous spatial restructuring is territorialization. In their view, globalization has restructured the Fordist, state-centered territorial matrix by transforming economic and state activity. Therefore, if bureaucratic states monopolize legal coercion within a territory (Weber 1971), emergent multi-scalar processes (Jessop 2001) that impinge on coercion and other fields of state activity have probably had an impact on that territorial matrix too.

The former general argument can be easily applied to education. For a long time bureaucratic states have extended compulsory schooling from lower to higher levels in order to unify their territory (Bendix 1974, Boli, Meyer and Ramírez 1985). In the end, most of them have committed to equalizing education (Meyer 2001), but education reforms inspired in competing political ideologies have not had a uniform impact on 'real' equalization. Whereas finance-driven education policy in fact threatens to exacerbate inequality (Carnoy 1999), a school system that lacks early selection, that is efficient in teaching and provides strong incentives for students to continue to a free or subsidized higher education is likely to promote equality (Jonsson and Erikson 2000: 377, Duru-Bellat, Mons and Suchaut 2004). The logic of induction departs from the former strategy but downplays the second kind of allegedly passive measures. In logical terms, it could strengthen and stretch 'real' equalization if activation was an effective leverage; conversely, if the expected effect was weak, equalization would not be the outcome. In political terms, emulation might not be enacted if this discourse was grounded on well-documented positive evaluations; conversely, the logic of induction can trigger emulation if it is not underpinned by reliable evidence and is associated with references to the inferior position of the needy. Then poverty assessments and anti- 
poverty interventions would expose this weak social category to the surveillance of more resourceful and prestigious local groups in the heterogeneous towns and regions of these immense countries, and would eventually contribute to hinder equalization.

But political global action sometimes produces unintended effects at lower-range scales. Certainly, the logic of induction is currently under attack and alternative anti-poverty guidelines could gain momentum in Southern America. This is the kind of tension that we can spell out if the logic of induction is defined as a discourse, because discourses reflect conflicts by representing the hierarchies established between certain social groups and expressing their identities and projects (Fairclough 2003). Notably, the official discourse on education provides very significant clues due to its location in the broader social structure (Bernstein 1990, 1996).

\section{Inducing the poor to emulate the non-poor}

So far previous research has sketched but has not yet analyzed the logic of induction systematically in Argentina (Duschatzky and Redondo 2000) and Chile (Berardi 2001). Fortunately, Fairclough (2000: 51-65) has published a documented analysis of the British policy against social exclusion that is very helpful to figure out how emulation can be an outcome of social policy. The British government has published several documents that see exclusion as a multi-dimensional but temporary phenomenon. They assume that anti-poverty strategies have to be personalized so that they tackle the allegedly heterogeneous and fluid factors of exclusion. However, as the concrete wording shows, a second implication entails that exclusion is a stable social condition instead of a process. Such a rhetorical shift dramatically limits the scope of action. In the end, the proclaimed concern with individualized solutions to a multi-dimensional problem is reduced to getting a low-paid job and changing the allegedly passive culture of the poor.

Similarly, in Argentina, Brazil and Chile the same arguments are often mentioned in order to defend educational anti-poverty policy. As I have already commented, regional organizations recall the multiple sides of human poverty, aim to empower the needy, and argue that targeting is an efficient strategy after the terrible 1980s (CEPAL 2002, World Bank 2004). To be precise, the logic of induction plays a major role in the continental political and academic publications as well as in our sample including governmental texts about educational targeting and interviews with policy-makers, program managers and head-teachers in Argentina, Brazil and Chile. The following empirical observations come from this source and have been collected in the three countries (see note 2).

In 1993 the National Education Ministry implemented the Social Educational Plan in Argentina at the same time as the bulk of educational competencies was transferred to regional governments. The plan operated until the late nineties delivering supplementary aid to the poorer schools in order to improve their facilities, management, pedagogic materials and student grants. Its name and institutional device changed later on, and its philosophy is currently challenged, but the main initiatives have persisted. In 1999 an evaluation reported a slight beneficial effect on school survival and performance. At that time a full ethnographic account nevertheless blamed the program for breaking the public service ethos of Argentinean schools. Certainly, such a perverse effect was due to financial shortcomings and policy contradictions 
between the Ministry and many provincias, but it was also the outcome of an intensive 'discursive work' that flooded schools and low paid teachers with lots of pedagogic materials they couldn't even read (Duschatzky and Redondo 2000). Although the dramatic political changes don't allow to attribute any linear effect to that initiative, it probably contributed to strengthen emulation. Significantly, nowadays hierarchical comparison is pervasive and persistent in spite of the new terrible widespread poverty: even more, parents and teachers keep comparing the more and less prestigious schools for the 'new' and the 'old' poor under these adverse general circumstances (Feijóo and Corbetta 2004). In some cases these comparisons are crudely poignant, because the poorest schools eventually work as social service centers providing day shelter and basic food instead of systematic teaching to their impoverished students. Our interviews have detected wide political debates about possible alternatives to educational targeting that could deal with such reality.

In Brazil educational targeting is alleged to be an instrument of the universal social right to education emphatically proclaimed by the constitution and the education act passed in the late eighties. Ten years later the Federal government realized that these objectives were not fully met, and implemented two targeted programs: one of them provided municipalities with incentives in order to increase enrolment and reinforce the weakest schools, the other one delivered grants to poor families in order to make enrolment sure and put a curb on child labor. For these years Federal, regional and local governments have launched their own schemes, and co-ordination problems have multiplied. Furthermore, some municipalities such as Belo Horizonte (Minas Gerais) and Porto Alegre (Rio Grande do Sul) have stretched the objectives by delivering bigger grants and implementing team- work in poor schools. Available evaluations report a positive impact on enrolment as well as a popular feeling that the less generous Federal and state programs discriminate some schools with respect to municipal programs. As a consequence, emulation is at stake in several ways, because not only inter-school differences become very visible, but also huge cultural distances become apparent between the educational style of poor families and the new pedagogic expectations (Tarabini 2004). Thus, critiques blame targeting for low co-ordination and uncertain impact on performance, whereas supporters attempt to expand both grants and pedagogic innovation.

In Chile rural, minority and low performing primary and secondary schools are targeted (see the Government of Chile- Mineduc 2004 website). Interviews and official documents have often illustrated the contradictions of such a variety of applications as well as several intended and unintended 'emulation impacts'. First, the primary education targeted program (900 Schools) was complemented with community development until 2003, when OECD published its data coming from the international student assessment that reported low performance and exacerbate disparities in the country. Then the program was downplayed by a new strategy that emphasized basic literacy and arithmetic skills, and the new targeted devices that were devised for the remaining 'critical schools' were privatized. Second, rural education has become a targeted program on the grounds that academic performance is lower and poverty rates are higher in rural areas. Thus, this program entails a combination of a selective strategy such as targeting and a universalistic strategy such as supplying school places to all the municipalities. However, this combination not only leads to a hierarchical comparison between rural and urban allegedly normal schools, but the program is also featured as a 
tool to halt emigration from rural areas towards the capital, which is a consequence of economic hardship due to seasonal agricultural work (Agacino 2003).

Third, the Chilean education policy is presented as a best practice inasmuch as it has transformed intercultural education into a targeting device (CEPAL 2002: 153). The program managers argue that it was the only feasible solution at the time of the democratic transition in 1990. Apart from the inevitable contention that this understanding opens with respect to curriculum contents and cultural rights, other derived strains clearly reproduce a game of hierarchical comparison connected with categorical inequality. For instance, the program seeks recognition and compensation simultaneously so that official performance objectives are eventually limited to a minimal progress far below the national average. Finally, in several interviews headteachers have openly declared that targeted schools concentrate students with psychological, social and even environmental (due to pesticides) problems, and sometimes have lived their inclusion into the 900 Schools Program as a stigma. These four partial findings sketch important connections between the logic of induction and emulation in Chile and portray the political conjuncture where it has received a sounder legitimization albeit opposition parties have already suggested to substitute it for excellence grants.

In summary, the analysis leads to two conclusions. On the one hand, target groups are supposed to be activated by means of economic aid and pedagogic support, but these expectations can be mere wishful thinking due to the second messages about control and stigma. Even worse, the logic of induction risks to become a sort of self-fulfilling prophecy that blames the victim, because it asks low performing schools and students to compare their adverse circumstances with remote educational ideals. Both in targeted and non-targeted schools teachers and parents retrieve a permanent categorical comparison whereby educational inequality is depicted as an objective, inexorable reality that can only be partially alleviated. At least, educational targeting has translated this image into a message for people engaged with the collapsing urban schools that only received some books and journals in Argentina, with the schools not included in the progressive municipal programs in many Brazilian cities as well as with the wide array of targeted 'special' schools in Chile. On the other hand, some policy-makers, some program managers and many teachers realize so important shortcomings of educational targeting that feel the need to look for alternative solutions. At the moment we can only observe this emerging political conflict. Certainly, more intensive and extensive anti-poverty policies could hinder the cumulative effect that the logic of induction and emulation produce, but at the moment these are so secondary, local or new proposals that we ignore if they are able to.

\section{Persistent Territorialization of Educational Inequalities}

Some estimations of educational inequalities in Argentina, Brazil and Chile have found out signs of a stable trend rather than a clear equalization. Although literacy, schooling and drop-out rates have improved, the rural- urban divide (at least, in Brazil and Chile) and regional disparities are almost constant.

\section{GRAPHIC 1}


In Argentina the average 15-to-24 years-old youth had studied for 7,8 years in 1980, for 9 years in 1990 and for 10,1 years in 2000 (CEPAL 2002). Since the nineties graduation has improved slightly at lower secondary education or EGB3, but coefficients of variation remain at the same level (Graphic 1). According to a recent report (CIPPEC 2003), regional disparities may have even grown up. Whereas some provincias have fully implemented the 1993 educational reform, others have been reluctant to do so. If they are compared, the conclusion is that basic educational indicators portray persistent (or maybe exacerbating) regional disparity. In Ciudad Autónoma de Buenos Aires (CABA), Río Negro and Neuquén, which have not implemented the reform at the higher courses of primary education, enrolment and drop-out rates have lagged behind the other regions. In secondary education the reluctant governments have been CABA, Entre Ríos, Jujuy, La Rioja, Neuquén, Río Negro and Tucumán. Although their drop-out rates are better than the average, their enrolment rates are worse.

\section{GRAPHIC 2}

In Brazil the youth went to school for 6,6 years in 1990 and 7,5 years in 2000, but the ratio between the urban and the rural average was the same as in 1979. Certainly, urbanrural gaps have been significantly reduced under democratic rule, but two important exceptions still show their persistence in recent times. First, during the nineties the ratio has worsened by decreasing further below 1 with regards to the less educated (with less than six years of schooling), because this group has only experienced a very low reduction in rural areas; second, there are almost no young people who have studied for more than thirteen years in these rural areas (Table 1). On the other hand, the trend of finished courses has recorded an increasing inter-state mean but a constant variation in the nineties (Graphic 2). Even more, UNDP (2003) has estimated that literacy advances in most regions of this big country except for the poor North East. This datum indicates how educational inequalities intermingle with changing territorialization, because the regional Northern stagnation contrasts with the powerful global links of Southern regions, where two global technological hubs have emerged in Sao Paulo and Campinas (UNDP 2001).

\section{GRAPHIC 3}

In Chile territorial stable educational inequalities appear at higher rates of enrolment, since the urban youth stay in the education system for the same ten years as their Argentinean neighbors, and the rural youth mean years of schooling are nine. But there are other signs of stability instead of equalization: the urban average has eventually stagnated, the urban- rural ratio has been almost constant at the level of the less educated, and university population (with 13 or more years of schooling) has not clearly increased in spite of secondary education growth (Table 1). Besides, more students have certainly passed their final exams at secondary education, but the variation of failure rates between regions has increased instead of decreased (Graphic 3).

\section{TABLE 1}

Comparative international studies don't report on inequality trends yet, but suggest some further clues about social change and educational inequality. As to literacy and enrolment, the Education Index of the three countries is close to the OECD 0,94 average, since it scores 0,94 in Argentina, 0,90 in Brazil and 0,89 in Chile (UNDP 2003). As to 
performance, their mean score is significantly low (OECD and UNESCO/UIS, 2003); however, Argentina and Chile record much more exacerbate inequalities than Brazil (Duru-Bellat, Mons and Suchaut 2004), and most Latin American education systems yield worse indexes of effectiveness and equity than these three cases (Willms and Sommers 2001). Thus, the resulting development trend portrays a multi-dimensional economic and educational crisis in Argentina, shows that Brazil avails of its lower GDP per capita in a more effective way for education, and records a mismatch between economic growth and educational development in Chile.

\section{Conclusion}

In the nineties the democratic governments of Argentina, Brazil and Chile drew on educational and social targeting in order to deal with poverty in a very complex conjuncture. Both the need to compensate for terrible inequality as well as the recommendations included in the global educational and social agenda inspired those decisions. Targeting was compatible with the financial conservatism promoted by the global economic policy agenda; and sub-national political scales also played a role due to the coincidence of targeting and de-centralization.

In my opinion, educational targeting has contributed to keep educational inequality stable in the three countries. This policy is actually an element of the official pedagogic discourse (Bernstein 1990, 1996) that can be defined as the logic of induction. Such logic entails that low achievers can be identified and successfully stimulated in the same way as low performing schools can be helped by means of pedagogic and economic support.

The logic of induction establishes the social norm of emulation (Tilly 1998) by compelling the disadvantaged to assimilate the social practices attributed to more prestigious social archetypes. According to some pieces of evidence, the former has actually intermingled with the latter: for instance, years ago targeted schools were flooded with books and leaflets without responding to their crude material problems in Argentina; nowadays, overlapping programs create new hierarchies between schools in Brazil, and targeting has become a one-size-fits-all solution for school failure, rural schooling and intercultural education in Chile.

The whole process provokes noticeable territorial consequences as far as the homogeneity of education systems and the deprived regions are concerned. Actually, in spite of some partial progress, the Economic Commission and the three governments report significant continuity concerning urban- rural gaps in schooling and regional disparities in secondary education.

This conclusion shouldn't suggest a static understanding nevertheless, because a discourse not only reflects interests and conflicts but can also raise opposition. Nowadays, new voices propose to re-design anti-poverty strategies in these three countries, either substituting targeting by wider choice opportunities, by reforming the logic of induction or simply by surpassing its selective scope. According to my analysis, so far targeting has allowed a wide room for emulation, but we still ignore whether its reforms or the alternative strategies can eventually constrain this room.

\section{Notes}


The paper has been produced within the GLOBDESAL research program Globalization and Inequalities in Latin America: educational and anti-poverty policies in Argentina, Brazil and Chile. It is funded by the Ministry of Science and Technology (Spain) and the European Regional Development Fund (Reference No. SEC2002-02480). The main researcher is Xavier Bonal (UAB) and the research team works within the Seminar for the Analysis of Social Policy (SAPS-Univ. Autònoma de Barcelona, Spain). The project avails of our collaboration with the EU-TN Globalization and Education Network in Europe (GENIE) and the UNESCO/ UNITWIN Medeuramérica Network for Human Development. Former versions were presented at the Encuentro de Latinoamericanistas (Univ. Salamanca, Spain, 2004) and the Symposium on 'Theorising Globalisation and Education', coordinated by Susan Robertson (Univ. Bristol) at the XXII World Congress of Comparative Education Societies (Havana Conference Centre, Cuba, 2004). I want to acknowledge and thank all the comments received there.

${ }^{2}$ In 2003 I interviewed a sample of policy- makers, program managers, educational consultants and headteachers in Chile. In 2004 Aina Tarabini and Oscar Valiente carried a similar fieldwork in Minas Gerais (Brazil) as well as Toni Verger did in Argentina. I would like to thank all of them and Professor Xavier Bonal (UAB) for recommendations and comments on the former versions of this paper.

\section{References}

Agacino, Rafael (2003) Chile Thirty Years After the Coup. Chiaroscuro, Illusions and Cracks in a Mature Counterrevolution. Latin American Perspectives, Issue 132, 30(5): 41—69.

Ball, Stephen (1994) Education Reform. An critical and post-structural approach London: Open University Press.

Bendix, Reinhardt (1974) Transformaciones experimentadas por las sociedades occidentales desde el siglo XVIII [Transformations of Western societies until the XVIIIth century]. In: Estado nacional y ciudadanía [National state and citizenship] Buenos Aires: Amorrortu.

Berardi, Lucia (2001) Globalization and poverty in Chile. Discourse and Society, 12(1): 47-58.

Bernstein, Basil (1990) The Structuring of Pedagogic Discourse. London: Routledge.

-- (1996) Pedagogy, Symbolic Control and Identity. Theory, Research, Critique London: Taylor and Francis.

Boli, John; John Meyer and Francisco Ramírez (1985) Exploring the Origins and Expansion of Mass Education. Comparative Education Review, 29 (2): 145-170.

Bonal, Xavier (2002) Plus ça change... The World Bank Education Policy and the PostWashington Consensus. International Studies in Sociology of Education, 12(1): 3-21.

-- (2004) Contra la pobreza... ¿desigualdad? La educación como estrategia de superación de la pobreza según el Banco Mundial. Algunos ejemplos de América Latina [Inequality against poverty? Education as a strategy to alleviate poverty according to the World Bank. Some Latin American examples] in: Gomà, Ricard and Jacint Jordana (eds) Descentralización y políticas sociales en América Latina [De-centralization and Social Policy in Latin America] Barcelona: Fundació CIDOB.

Bourdieu, Pierre and Loïc J.D. Wacquant (2002) Réponses. Pour une anthropologie réflexive [Replies. For a Reflexive Anthropology] Paris: Editions du Seuil.

Brenner, Neil (1999) "Globalisation as Reterritorialisation: The Re-scaling of Urban Governance in the European Union". Urban Studies, 36(3): 431-4 51.

Buchmann, Claudia and Emily Hannum (2001) Education and Stratification in Developing Countries: A Review of Theories and Research. Annual Review of Sociology, 27: 27-102.

Carnoy, Martin (1999) Globalization and educational reform: what planners need to know Paris: UNESCO/ IIEP.

Castro, Ricardo de Moura (2000) Reforming primary and secondary education in Latin America. An IADB strategy, Publication EDU-113, http://www.iadb.org, accessed April 2004.

Comisión Económica para América Latina y el Caribe-CEPAL, Economic Comission for Latin America and the Caribbean- (2002) Panorama Social de América Latina, http://www.eclac.org, accessed December 2004.

Centro de Implementación de Políticas para la Equidad y el Crecimiento -CIPPEC, Centre for Equity and Growth Policy Implementation- (2003) Proyecto 'Las Provincias Educativas' [Project 'Educational Regions'], Documentos de Trabajo $\mathrm{n}^{\circ} 1,2$ and 3, http://www.cippec.org, accessed July 2004. 
Dale, Roger (1989) The State and Education Policy London: Open University Press.

- (1999) Specifying Globalisation Effects on National Policy: focus on the Mechanisms. Journal of Education Policy 14 (1): 1-17.

- (2000) Globalisation and Education: Demonstrating a 'Common World Education Culture' or Locating a 'Globally Structured Educational Agenda'?. Educational Theory, 50 (4): 427-448.

Duru- Bellat, Marie, Nathalie Mons and Bruno Suchaut (2004) Caractéristiques des systèmes éducatifs et compétences des jeunes de 15 ans. Éclairage des comparaisons entre pays. Les Cahiers de l'IREDU, 66 [Educational systems and performance of the 15 year-olds. Making sense of comparisons between countries, IREDU Working Papers], http://www2.ubourgogne.fr/IREDU, accessed February 2005.

Duschatzky, Silvia and Patricia Redondo (2000) Las marcas del plan social educativo o los indicios de ruptura en las políticas públicas [The marks of the social plan or broadening divide in public policies] In: Duschatzky, Silvia (comp) Tutelados y asistidos: programas sociales, políticas públicas y subjetividad. [Surveillance and assistance: social programs, public policies and subjectivity] Paidos; Buenos Aires.

Fairclough, Norman (2000) The Language of 'Social Exclusion. In: Fairclough, N. New Labour, New Language? Routledge: London and New York.

-- (2003) Analysing Discourse: Textual Analysis for Social Research London: Routledge.

Feijoo, Maria del Carmen and Silvia Corbetta (2004) Escuela y pobreza. Desafios educativos en dos escenarios del Gran Buenos Aires [Schooling and Poverty. Educational Challenges in Two Settings in Big Buenos Aires] Buenos Aires: IIPE-UNESCO.

Government of Argentina- Ministry of Education and Science MEC-DNIECE (2002) Changes in the Argentinean educational system between 1990 and 2000 (in Spanish: report by I. Oiberman and M.A. Arrieta) http://www.me.gov.ar, accessed March 2004.

- Ministry of Education an Science MEC (2004) National Program of Student Grants [in Spanish] http://www.me.gov.ar/dnpc/areasybecas.html, accessed June 2004.

Government of Brazil- Ministry of Education ME (2002) School Grant Program http://www.mec.gov.br, accessed June 2004.

--(2004) Educational Statistics http://www.mec.gov.br, April 2004.

Government of Chile- Ministry for Development and Planning MIDEPLAN (2000) Education in Chile [in Spanish], http://www.mideplan.cl, accessed October 2004.

- Education Ministry MINEDUC (2002) Innovation in Equity and Diversity. 900 Schools Program, Report for UNESCO [in Spanish] http://innovemosp.unesco.cl, accessed April 2004.

- Education Ministry MINEDUC (2003) SIMCE Examination $8^{\text {th }}$ Basic. National Results [in Spanish] http://www.mineduc.cl accessed October 2004.

- Education Ministry MINEDUC (2004) High School for All Program http://www.mineduc.cl/media/lpt, accessed June 2004.

Green, Andy (1999) Education and globalization in Europe and East Asia: convergent and divergent trends. Journal of Education Policy, 14(1): 55-71.

Harvey, David (2000) Spaces of Hope Edinburgh: Edinburgh University Press.

Jessop, Bob (2001) On the Spatio-Temporal Logic of Capital's Globalization and their Manifold Implications for State Power, paper published by the Department of Sociology, Lancaster University at: http://www.comp.lancs.ac.uk/sociology, accessed October 2003.

Jonsson, Jan O. and Robert Erikson (2000) Understanding Educational Inequality: The Swedish Experience. L'Anée Sociologique, 50(2): 345-382.

OECD (2002) Education at a Glance Paris: OECD, http://www.oecd.org accessed October 2003. -- and UNESCO/UIS (2003) Literacy Skills for the World of Tomorrow- Further Results from PISA 2000, http://www.oecd.org, accessed April 2004.

Meyer, John W. (2001) The Worldwide Commitment to Educational Equality. Sociology of Education, Extra Issue: 154-158.

Nussbaum, Martha (2000) Women and Human Development: The Capability Approach Cambridge: Cambridge University Press.

Popkewitz, Thomas S. (1994) Sociología política de las reformas educativas [Political Sociology of Educational Reforms] Madrid: Morata. 
Robertson, Susan, Xavier Bonal and Roger Dale (2003) GATS and the Education Service Industry: The Politics of Scale and Global Reterritorialization. Comparative Education Review, 46(4): $472-496$.

Sen, Amartya (1999) Development as Freedom Oxford: Oxford University Press.

Strange, Susan (1996) The Retreat of the State Cambridge: Cambridge University Press.

Tarabini, Aina (2005) Globalization, Targeting and Anti-Poverty Policy: a case study of Program Bolsa Escola in Belo Horizonte, Brazil Barcelona: MA in Sociology Dissertation, Universitat Autònoma de Barcelona.

Tedesco, Juan Carlos and Néstor López (2002) Desafíos de la educación secundaria en América Latina [Challenges of Secondary Education in Latin America]. Revista de la CEPAL, 76: 55-69. Tickly, Leon (2004) Education and the new imperialism. Comparative Education, 40(2): 173198.

Tilly, Charles (1998) Durable Inequalities Berkeley: University of California Press.

UNDP (2001, 2003, 2004) Human Development Report http://www.undp.org (accessed June 2004).

Walberg, Herbert J. and Guoxiong Zhang (1998) Analyzing the OECD Indicators Model. Comparative Education, 34(1): 55-70.

Weber, M. (1971) Economía y sociedad [Economics and Society] Madrid: Edicusa.

Willms, John D. and Marie A. Sommers, (2001) School Results in Latin America New Brunswick: Canadian Research Institute for Social Policy (available in Spanish at http://www.unesco.org, accessed April 2003).

World Bank (2001) World Development Report 2000/2001. Attacking Poverty. Overview http://www.worldbank.org, accessed May 2002.

-- (2004) Inequalities in Latin America. Breaking with the Past? http://www.worldbank.org, accessed June 2004. 
Graphic 1 Graduation Rates in Primary and Secondary Education (Argentina, 1996-9)

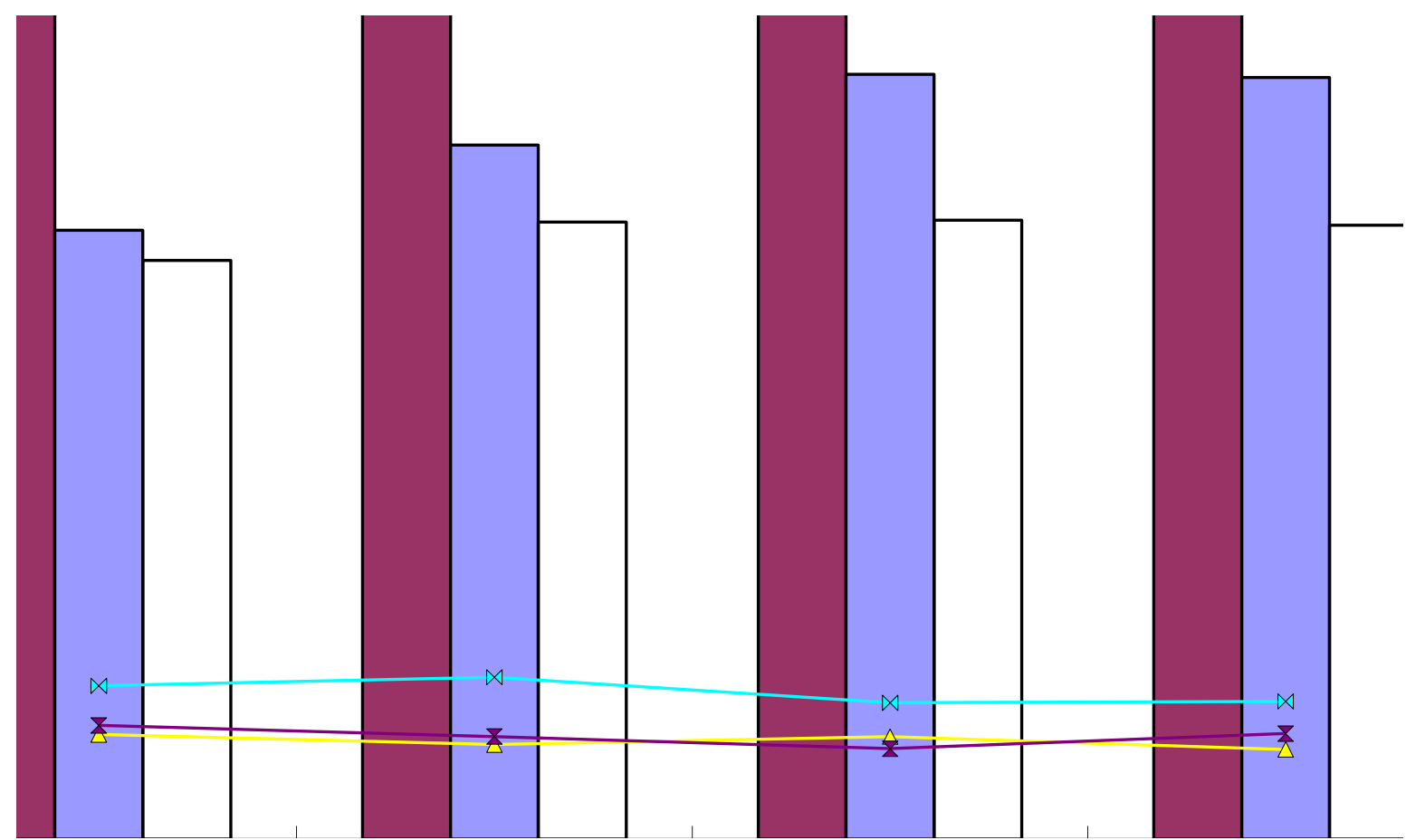

Source: Government of Argentina- Ministry of Education and Science (2002)

Graphic 2 Expected and effective educational results (Brazil regions, 1995-2000)

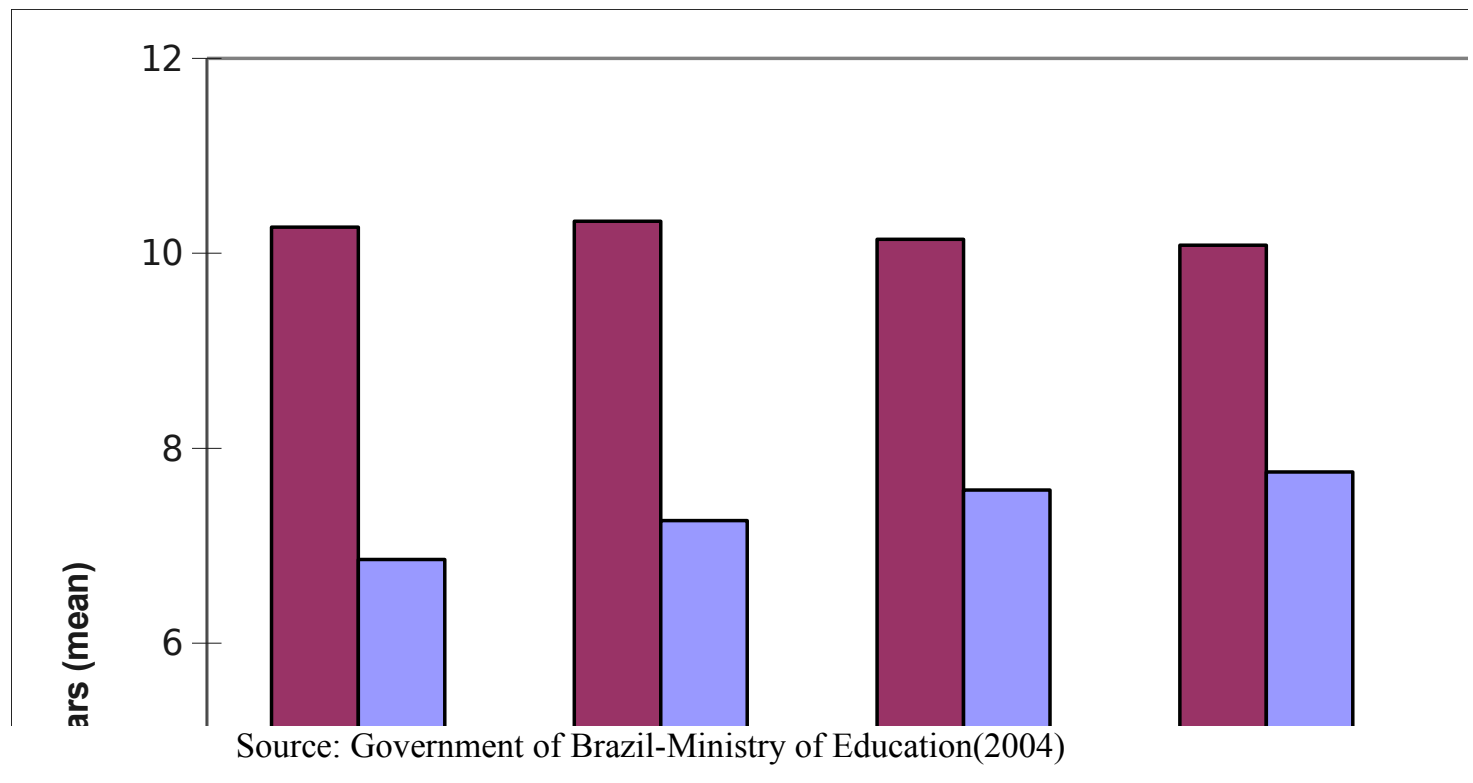


Graphic 3 Pass, Failure and Drop-out Rates in Secondary Education (Chile, 19902000)

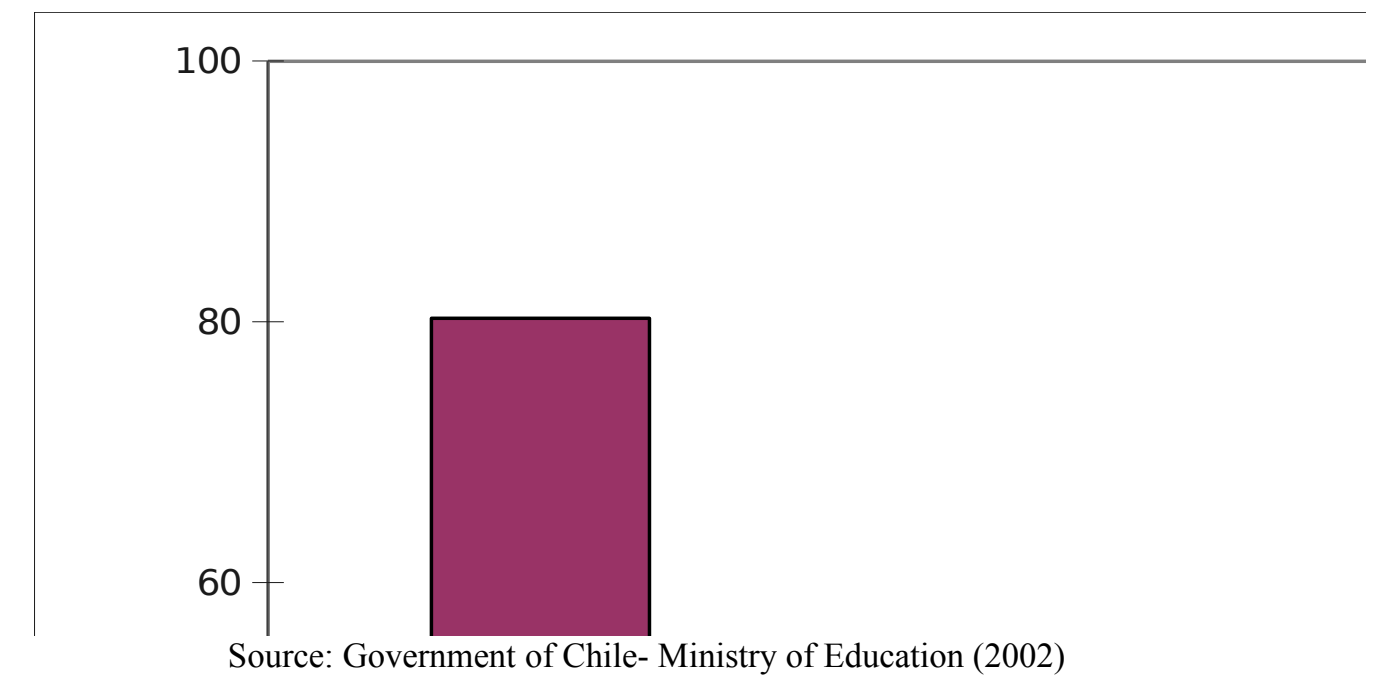

Table 1: Years of schooling, 15-24 years old population, Brazil and Chile

\begin{tabular}{l|ccc|cc|}
\hline & \multicolumn{3}{|c|}{ Brazil } & \multicolumn{3}{c|}{ Chile } \\
\cline { 1 - 3 } Mean years & $\mathbf{1 9 7 9}$ & $\mathbf{1 9 9 0}$ & $\mathbf{2 0 0 0}$ & $\mathbf{1 9 9 0}$ & $\mathbf{2 0 0 0}$ \\
Urban zones & & & & & \\
Rural zones & 6,4 & 6,6 & 7,5 & 10,1 & 10,6 \\
Urban-rural ratio (equality =1) & 4,2 & 3,6 & 4,9 & 7,9 & 8,9 \\
Less than 6 years of schooling (\%) & 1.5 & 1.8 & 1.5 & 1.3 & 1.2 \\
Urban zones & 48,2 & 41 & 27 & 5,6 & 2,7 \\
Rural zones & 86,8 & 79 & 62,8 & 16,9 & 8,5 \\
Urban-rural ratio (equality=1) & 0.6 & 0.5 & 0.4 & 0.3 & 0.3 \\
Between 6 and 9 years of schooling & & & & & \\
(\%) & & & & & \\
Urban zones & 34,6 & 37,5 & 42,7 & 33,1 & 30,1 \\
Rural zones & 9,7 & 16,9 & 27,2 & 56,5 & 49,9 \\
Urban-rural ratio (equality=1) & 3.5 & 2.2 & 1.6 & 0.6 & 0.6 \\
Between 10 and 12 years of schooling & & & & & \\
(\%) & & & & & \\
Urban zones & 14,1 & 18,2 & 26,7 & 45,5 & 51,1 \\
Rural zones & 1,9 & 3,7 & 9,5 & 22,6 & 37 \\
Urban-rural ratio (equality=1) & 7.4 & 4.9 & 2.8 & 2 & 1.4 \\
More than 12 years (\%) & & & & & \\
Urban zones & 3,1 & 3,3 & 3,7 & 15,8 & 16,2 \\
Rural zones & 1,6 & 0,3 & 0,5 & 4,1 & 4,6 \\
Urban-rural ratio (equality=1) & & & & 3.8 & 3.5 \\
\hline
\end{tabular}

